\title{
Employee Choice Of Voice: A New Workplace Dynamic
}

Sandra Jeanquart Miles, Murray State University, USA

Gerry Nkombo Muuka, Murray State University, USA

\begin{abstract}
Employee voice - an emerging strand of contemporary organizational communication-is quickly becoming one of the most important workplace phenomena of our time thanks, in large part, to increases and improvements in the depth and breadth of technology. Technological breakthroughs have inspired new ways for employees to voice their satisfaction and dissatisfaction in the employment place in ways that were not possible only a decade ago. Social media such as Facebook, Myspace and LinkedIn as well other chat-rooms and blogs can now reach vast national and international audiences with messages that may or may not be organizationally desirable or sanctioned. The article traces the emergence of employee voice mechanisms and types, especially as the latter relates to these technology-inspired social media. The article's central contribution is to be found on many levels including, but not limited to: helping the reader to understand how an employee's choice for a voice mechanism is no longer the exclusive preserve of the organization they work for; reviewing the contextual organizational parameters that determine how and what a propensity of employees are likely to choose as their voice mechanisms; and recommending a strategy for developing and managing employee voice to enhance and sustain an organization's competitive advantage.
\end{abstract}

Keywords: employee voice; employee branding; social media; psychological contracts

\section{INTRODUCTION}

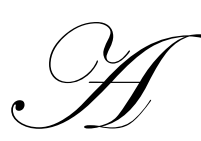

good starting example of how Social Media has started to change the workplace dynamic involves Jive Software. After cutting 20 percent of its staff, the company witnessed a turn of events it had not seen previously. One of the employed they let go used the internet to "blog" about their experience. With an angry tone, the employee told his large online audience about the personal belongings that he was forced to leave behind as a result of his firing, including his wedding photograph that had so much emotional value to him (Miller, 2008). Joining in the conversation, one member of the internet audience now glued to his story had only one thing to say, that is, "...from your description of events, it appears the positive Jive work environment was the first to go" (Miller, 2008). The company had underestimated the potential reaction to its move, and eventually allowed the employee back to pick up his belongings. But that was not before Jive Software's long-standing reputation had suffered irreparable damage.

With the depth, breadth and variety of technological breakthroughs in the $21^{\text {st }}$ century changing at unheard-of speeds, the mechanisms for employee voice are no longer limited to the internal systems orchestrated or sanctioned by the organization. There are websites dedicated to entire companies, and not sanctioned by them, in which employees can post negative and disparaging comments about their employer (See, for other examples: www.wakeupwalmart.com). Some websites are dedicated to encouraging workers from any organization to vent about their employers, for instance www.glassdoor.com, or www.jobschmob.com.

Social networking sites such as Myspace, Facebook and Linked-In all strive to network people together and host a space for them to post online journals and messages that are accessed by many friends. Along these same lines is the newest and fastest growing phenomenon, according to the New York Times. This phenomenon is Twitter, which allows users to send and receive "tweets" on Twitter's website via instant messaging or mobile 
phones, as the case may be. These tweets are circulated in a public domain among friends, followers and strangers who find the individual's tweets interesting (Pontin, 2007). What is more, anyone with a webcam can now broadcast live streaming video through $\underline{w w w . j u s t i n . t v}$, for anyone and everyone to see.

Contemporary technology can now reach national, regional, and international audiences with messages or images that may or may not be organizationally desirable or sanctioned. This point is made clear by Baker and Green (2008) who make the following argument:

Every e-mail or memo could be blogged. Every employee, no matter what rank could become a voice for the company, either publicly or cloaked, some gaining more power than the entire public relations department ( $p .45)$.

In essence, the stakes for organizations not recognizing or managing alternative voice systems may result in an unrecoverable disaster, or at least a public relations nightmare. It is worth noting that mechanisms for managing employee voice have a significant impact on commitment (Blinder, 1990). Opportunities abound for organizations that understand the new dimensions of voice and choose to harness the power of all available voice systems. These organizations can realize a sustainable competitive advantage through employees. Hence the purpose of this article is four-fold, that is: (a) to trace the emergence (and emerging) employee voice mechanisms and types, especially as the latter relates to technology-inspired social media; (b) to understand how an employee's choice for a voice mechanism is no longer bound by an organization; (c) to examine the organizational context as a determining factor in identifying how and what a propensity of employees are likely to choose as their voice mechanisms; and, finally (d) to propose a strategy for developing and managing employee voice to enhance and sustain an organization's competitive advantage.

\section{THE LITERATURE ON EMPLOYEE VOICE}

Employee voice-an emerging strand of contemporary organizational communication - is quickly becoming one of the most important workplace phenomena of our time. This is due, in large part, to increases and improvements in the depth and breadth of communications technology. As a concept, employee voice is not new. It dates back to the work of early proponents such as Albert Hirschman (1970), who defined voice from a marketing perspective as "any attempt at all to change rather than escape from an objectionable state of affairs" (p. 30). Hirschman employed a broad economic-political analysis of organizational deterioration versus maximization of its profit potential to propose his widely cited theory of exit, voice, and loyalty. Central to Hirschman's (1970) theory was the idea that when employees confront unsatisfactory conditions at work, they either exit the organization, or voice their concerns. At its most basic level, employee voice is the expression of opinions and concerns about organizational phenomena (Kassing, 2002) that may reveal content (agreement, suggestions, argument, support) or discontent (disagreement, contradictory opinions, and/or divergent views: Edmondson, 2006). Voice as active dissent due to dissatisfaction was central to much of the research following Hirschman's work. Those who adapted Hirschman's work, including management scholars, dwelt on investigation of the concept of voice and how it is manifested in the workplace.

Freeman and Medoff (1984), pioneers in voice research, presented a solid case for the importance of voice mechanisms for both employees and employers. They concluded that unions provided the best voice systems for participation as well as a venue for airing grievances within the organization. McCabe and Lewin (1992) broadened the area of voice by suggesting that employee voice can be articulated through a variety of mechanisms. As a result of their work, employee voice was then described as consisting of two elements, namely: expression of complaints or grievances and participation of employees in the decision making process. McCabe and Lewin (1992) further refined voice into either mandatory systems (codetermination) or voluntary systems (collective bargaining). Millward, Bryson, and Forth (2000) expanded on their definition of voice to include direct employee involvement.

Based on the existent research in the voice arena, Dundon, Wilkinson, Marchington, \& Ackers (2004), compiled the meaning of voice into four principal strands of thought, namely: articulation of individual dissatisfaction, expression of collective bargaining, contribution to management decision-making, and demonstration of mutuality and co-operative relations. Dundon and others (2004) concluded that employee voice is a complex and uneven set of meanings and purposes with dialectic shaped by external regulation on one hand, and 
internal management choice on the other. Research has also focused on mechanisms that enable voice in organizations without the assistance of collective bargaining units. Some of the mechanisms examined include participation in decision making, empowerment, grievance systems and leadership practices (Detert, Burris, 2007; McCabe, \& Lewin, 1992). These studies recognize the importance of employee voice in order to glean integral employee insight into organizational issues (Royer, Waterhouse, Brown \& Festing, 2008), as well as providing employees with an organizational channel through which dissatisfactions can be addressed within the system.

While Van Dyne and Le Pine (1998) suggest that constructive voice behavior is necessary for continuous improvement and organizational adaptation, the precise relationship between voice systems and performance outcomes continues to remain unclear (Dundon, Wilkinson, Marchington, \& Ackers, 2004). This may be associated with Harlos' (2001) findings that when organizations fail to respond to voice mechanisms employees experience increased dissatisfaction. The study also noted that informal systems such as open door policies were particularly problematic. The effectiveness of the systems appears contingent on leader behavior and acceptance (Detert, Burris, 2007), and all are organizationally sanctioned. However, with the onslaught of new technology neither the collective employee systems found in unions, nor the traditional voice mechanisms instituted by organizations are the only options available to employees for voice mechanisms. As such, recognition must be given to both organizationally sanctioned and non-sanctioned mechanisms. Employee voice messages can be functional (positive) in reinforcing an organization's desired image. But they can also be dysfunctional (negative) if not handled properly and can, consequently, detract from an organization's desired image and its desire for competitive advantage.

The Jive Software scenario in the introduction to this article is a lucid illustration of the changed frontiers and current state of the literature on employee voice, triggered largely by developments in social media. The case highlights an employee voicing dissatisfaction via a non-organizationally sanctioned medium, and a truthful message that was destructive to the organization's reputation. Other organizations have successfully captured employee voice through new media, and have been able to use it for a competitive advantage. "Blue Shirt Nation (BSN)" is an example of a blog utilized by Best Buy to glean employee reaction and feedback-positive or negative. Not only did it educate management about what was happening at the sales level, it also allowed for employees helping employees at all locations ( $\mathrm{Li}$ and Bernoff, 2008). As a listening device to what employees were saying, management discovered that a new policy regarding employee discounts was causing much unrest. Employees voiced their dissatisfaction, management listened and realized that the employee discount was critical in attracting and retaining employees and therefore rescinded the new policy (Li and Bernoff, 2008).

Understanding voice in light of the new media is pivotal, especially given that $54 \%$ of bloggers are under age 30, with $76 \%$ of them stating their reason for blogging as documenting and sharing personal experiences. It can be expected therefore that blogospheres will become a mainstream business communication strategy (Richmond, 2006). HRM Guide (2006) notes that blogging has increased by 16 percent, both from dissatisfied employees as well as customers. In its simplest sense, the argument can be made that anyone with an internet connection can be a global publisher. With research indicating that individuals will say or do things on the internet that they would not ordinarily do in real life (Kayany, 1998; Niemz, Griffiths, \& Banyard, 2005), this may have a negative impact for those organizations where a competitive advantage has not yet been realized. On the other hand, organizations that value the new voice mechanisms and manage them well have a clear advantage in realizing and sustaining a competitive advantage.

Traditional ways of airing views, by employees, are now augmented by new opportunities, choices and challenges that reach far beyond traditional definitions, channels and purposes. In light of this, a new and broader definition of voice that entails channels, purposes, and messages is needed. In this article, employee voice is viewed as an employee's attempt to express organizational experiences and issues; or to influence the organization, its members, or other stakeholders through either organizationally sanctioned or unsanctioned media including, especially in this case, social media such as Facebook and Myspace.

A logical question is raised, at this stage, regarding whether it is possible to predict employee voice and choice of voice medium in an organizational context. This is a key question in an attempt to not only understand the influencers of voice, but ultimately to also limit the potential for negative organizational impacts of employee voice. The section that follows addresses this issue. 


\section{PREDICTING EMPLOYEE VOICE AND CHOICE USING THE ORGANIZATIONAL CONTEXT}

Past research has identified some influencers of employee voice. These variables looked at both individual characteristics as well as organizational influencers. The choice of an employee to voice was often found to be prosocial in nature. In essence, the focus was to benefit others rather than oneself (Van Dyne et al. 2003). However, other researchers trying to account for more variance in voice behavior found a strong relationship with voice as a self oriented behavior, specifically as a means of impression management (Fuller et al. 2007). In sum, voice can be self-serving or pro-social, and capturing both elements is pivotal to garnering a competitive advantage.

Detert and Burris (2007) examined the role of leader behavior and improvement oriented voice. They found that managerial openness is more consistently related to voice than are transformational leadership styles. They also found that subordinate perceptions of psychological safety are a determining factor in the employees' choice to voice. As Milliken, Morrison, \& Hewlin (2003) and Ryan \& Oestrich (1998) point out, many employees do not operate in environments where it is safe to speak up. Harlos (2001) also noted that the perception employees had of managements' past responses to voice behaviors was a strong influencer in a person's choice to voice. Hence, new media allowing for an undisclosed identity may be appealing to employees who do not operate in "psychology safe" environments.

The foregoing studies certainly give a good indication that individuals within the organization will be influenced by managerial behavior, as well as by potential personal costs. Examining a broader organizational context may hold the key to understanding an employees' choice to voice using organizationally sanctioned or unsanctioned mechanisms, including whether messages would be destructive or constructive to the organizations' image. Dveloping an understanding of the organizational environment and its relationship to voice may therefore offer a better understanding of voice behavior.

Mangold and Miles (2007) have defined employee brand as the image that organizations present to their customers and other relevant stakeholders through their employees. This image can be positive or negative, contingent on the communication emanating from organizational message systems. Organizational message systems are characterized as external or internal, and formal or informal. The extent to which the organizational message systems consistently reflect the mission, values, and desired brand image of the organization, the greater the employee knowledge of the desired brand image and the more likely the employees are to deliver the desired brand image when the psychological contract is intact. In fact, Mangold and Miles (2007) suggested that one of the ways to alleviate negative blogging is through managing the employee brand. Using the different organizational types we can predict the voice behavior and the extent to which message content may be constructive or destructive, as well as the likelihood of using organizationally sanctioned mechanisms.

The Mangold and Miles (2007) typology classified organizations into four categories based on a preponderance of the employee's knowledge of the organization's desired brand image, and the extent to which the employee's psychological contract is upheld. Based on the interaction of these two dimensions, organizations fall into one of four major classifications: All Stars, Strike-Out-Kings, Injured Reserve, and Rookies. Mangold and Miles (2007) define rookie organizations as those where a majority of employees do not know or understand the organizational brand image. Although there is no clarity on the type of image the organization is trying to present to the public, employees in rookie organizations still perceive their psychological contracts as intact. Employees whose psychological contracts are intact are motivated, satisfied, committed, and perform at higher levels and tend to trust the organization (Rousseau, 1995; Robinson, 1996; and Niehoff \& Paul, 2001). Under this scenario, employees are good corporate citizens and always try to do what they think the organization wants. If the organization encourages the use of voice systems (i.e. blogging) from employees at a corporate sanctioned site, it can be expected that employees would participate. It can also be expected that the contents of the message would not be intended to harm the organization, but rather to contain items that the individual employee feels pertinent to portraying the organization in the light they perceive the organization wants to be portrayed in. However, a lack of clarity of the organization's mission, values, and desired brand image may or may not reflect the desired image the organization is wishing to offer to its stakeholders. Hence the following propositions are offered: 
P1: The messages communicated by employees of rookie organizations will be neutral with no intention of harming the organizations' desired image.

P2: Employees of rookie organizations will use voice mechanisms that are sanctioned by the organization.

P3: Organizational experiences relayed on social networking sites will be related to personal experience, which may or may not reflect the desired brand image of the organization.

The injured reserve organization is one characterized by a propensity of employees that have knowledge and understanding of the organizational image the organization wants them to deliver to the organizational constituents. However, the psychological contract of these employees, as a whole, has been violated through inconsistent messages they have received from organizational message systems. Inconsistent messages and violations of psychological contracts result in employee perceptions that fewer obligations are owed to the organization (Mangold \& Miles, 2007). Depending on the severity of the breach, employees will be less satisfied, motivated, and less likely to engage in organizational citizen behavior (Rousseau, 1989). In essence, these employees know the image the organization wants them to present, but are fairly frustrated with the manner in which they have been treated by the organization. In an environment where employees experience distrust, it is quite likely that they will not feel "safe" in speaking up. Milliken et al. (2003) and Ryan \& Oestrich (1998) make the argument that this is likely to have an impact on an employee's voice behavior. To this end, the following propositions are offered:

P4: The greater the perceived breach in the psychological contract of employees of injured reserve organizations, the more likely the employee will use voice mechanisms not sanctioned by the organization, with either a real or cloaked identity.

P5: The more the perceived breach in the psychological contract of employees of injured reserve organizations, the greater the propensity that the message will be destructive to the organization's desired image.

P6: Organizational experiences relayed on social networking sites will reflect negative experiences within the organization as perceived by the employee.

Employees of Strike Out King organizations neither know the desired brand image, nor receive consistent messages from the organizational system to uphold their psychological contract (Mangold and Miles, 2007). These employees are often confused by the conflicting agendas of internal and external message systems. Employees operating in this type of context are likely to engage in word-of-mouth communication to all who will listen (Mangold and Miles, 2007). In this type of organization, psychological contracts are breached, and the preponderance of employees view fewer obligations to the organization. In addition, because of the perceived duplicity of the organization, psychological safety in using voicing mechanisms is suspect at best. In this regard, the following propositions can be advanced:

P7: Employees of Strike Out King organizations will more likely engage in voice mechanisms not sanctioned by the organization, either with a cloaked identity or an uncloaked one.

P8: Employees of Strike Out King organizations will express destructive messages about the company through non-organizationally sanctioned mechanisms.

P9: Organizational experiences relayed on social networking sites will be destructive in nature regarding the company and its practices.

All Stars are those organizations that have successfully communicated their desired brand image to employees, and have managed psychological contracts quite well. The management of all of the organizational message systems yields employees who are highly motivated, committed, and tend to trust the organization. Because the psychological contracts are intact (in that they perceive the organization as delivering on its promises) employees are obligated to the organization to perform at the expected level. All Star organizations are 
characterized by employees who know the desired brand image and are willing to deliver that image to organizational constituents and stakeholders.

Southwest Airlines (SWA), a company whose employees deliver their desired brand image (Miles and Mangold, 2005), have successfully taken the proactive approach and recognize the voice mechanism of blogging as a tool to reinforce the organizational image and present life at Southwest with public access. They have clearly stated their "blogging" goal as follows:

Our goal with this blog is to give our readers the opportunity to take a look inside Southwest Airlines and to interact with us. This is as much your blog as it is ours. We have lined up a crew of bloggers representing a diverse crosssection of our Company (http://www.blogsouthwest.com).

The Southwest Airlines blog is divided into categories based on potential interest such as "pilots", "under the hood", "nutty stuff", and "happenings". The blog clearly reflects the well known culture of Southwest airlines, and gives great insight into what the airline is about. Clearly, allowing employees to blog is a risk, but the organizational context in which employees function has created a sustainable competitive advantage for the airline (Miles and Mangold, 2005).

Southwest Airlines is even using social media techniques in laying the groundwork for their merger with Air Tran Airways (http://www.lowfaresfarther.com/). This website provides information and a communication source for investors, current SWA employees, and Air Tran.

Employees of All Star organizations have their psychological contracts intact, and have full knowledge of the image the organization wishes to express to its stakeholders. Based on this, the following propositions can reasonably be advanced:

P10: Employees of All Star organizations will use organizationally sanctioned voice mechanisms.

P11: Employees of All Star organizations are likely to express constructive and positive comments about their organization to constituents and stakeholders.

P12: Organizational experiences relayed on social networking sites will contain positive work experiences.

Understanding the organizational context and potential use of voice mechanisms available for employees is extremely important. The new technological dynamics may impact traditional manners in which employees respond to dissatisfaction. Farrell (1983) identified four responses, namely: exit, voice, loyalty, and neglect. While these certainly reflect on job behavior, other voice mechanisms abound to encourage new responses off the job with a much larger audience. An example is where employees that are on the job "appearing to be loyal", or even "silent sufferers" may in their off time, seek to respond to dissatisfaction at work through voice mechanisms that allow their identities to be cloaked with virtually little fear of reprisal. Hence, understanding the new dynamics of employee voice is pivotal to developing and managing effective employee voice mechanisms. The section that follows elaborates on this central argument.

\section{TOWARDS BEST PRACTICES FOR MANAGING EMPLOYEE VOICE}

Organizational leaders seeking to glean a strategic competitive advantage from employees will have to carefully orchestrate organizationally sanctioned voice mechanisms. While control of voice messages to nonorganizationally sanctioned venues is at best difficult, organizations can still manage the messages conveyed by employees through these non-sanctioned mechanisms. The key to managing these types of messages lies in the employee brand process as presented by Miles and Mangold (2005). They present a comprehensive approach to aid organizations to transform their organizations into All Stars. One of the objectives of this article is to develop a strategy that integrates voice mechanisms into the organization, as these organizations evolve into All Stars. The key to orchestrating organizationally sanctioned mechanisms is housed in a five step process, namely: set the objective or purpose of the voice system, select the tactics to achieve the objectives, listen to employee voice, respond and dialogue with the employees, and finally use the voice system to energize and connect employees. Each of these is elaborated upon. 


\section{Setting the Objective Or Purpose Of The Voice System}

Like any other initiative, choosing a voice system to meet organizational needs requires the organization to look at the organizational type as discussed above, and what it wants to accomplish through its voice system. Organizational types depend on the extent to which psychological contracts have been upheld, as well as the knowledge employees have of the organization's desired image. As a result of these differences, organizations have different levels of trust impacting both the perceived psychological safety of employees and the perceived responsiveness of management to voice mechanisms. In other organizations, employees may not have a clear idea of the image the organization would like to be portrayed, and yet this is vital to achieving some of the organization's loftier goals. For instance, it may be that a Strike Out King organization may desire a voice mechanism to allow for employees to help other employees. However, the dynamics of organizations characterized by low knowledge of the organization's desired image coupled with broken psychological contracts among employees would render an environment in which "psychological safety" may not be perceived by employees. In addition, these employees are also not clear on the desired image the organization wishes to project. A voice system for employees helping other employees may not be realized until the overarching issues of psychological safety and psychological contract breaches are resolved. Once these issues are resolved, the organization can work to clarify the desired image and values they want their employees to portray when interacting with each other and with organizational constituents. Only when these two basic goals are reached can organizations move to loftier goals of employees helping other employees.

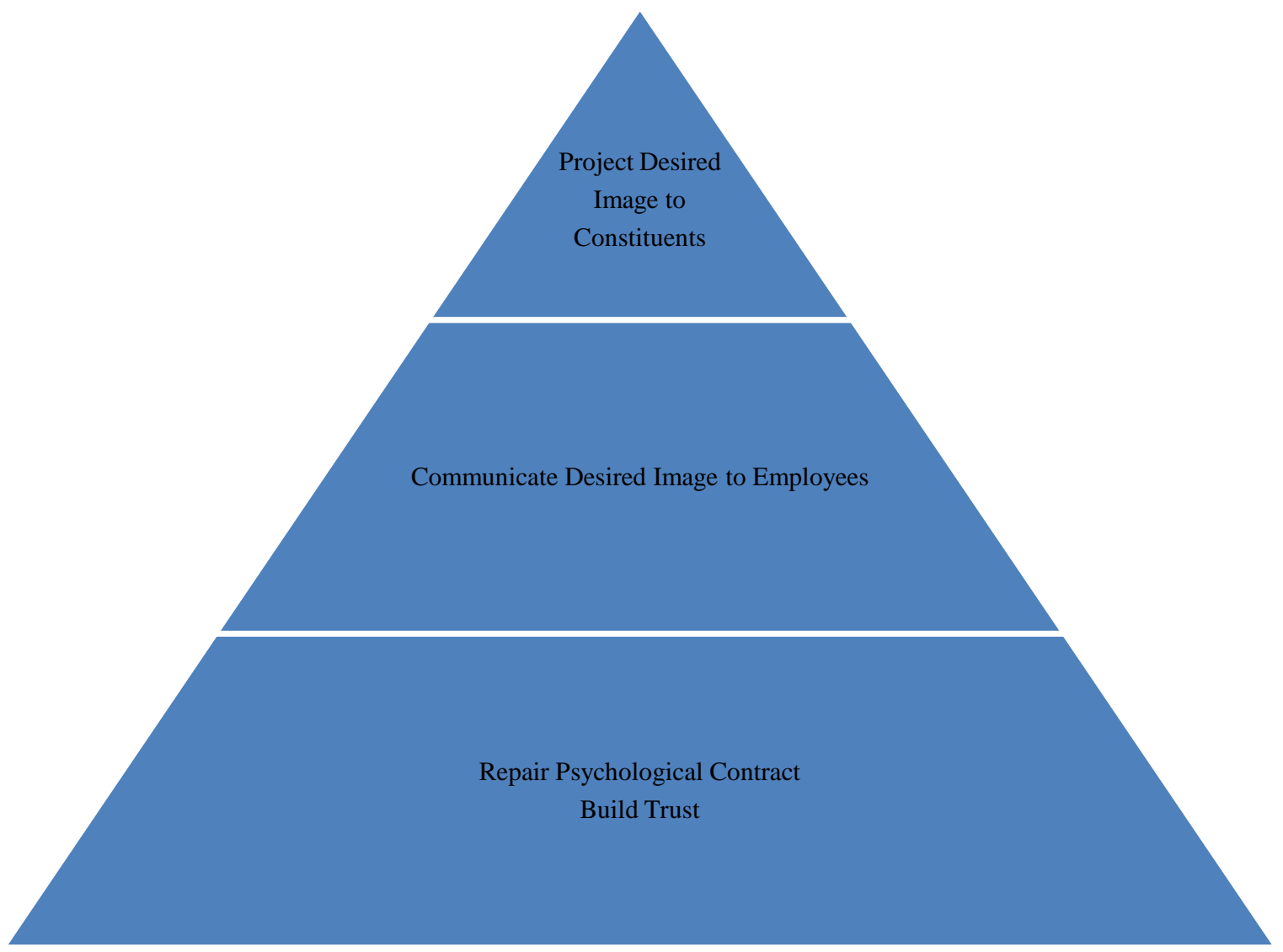

Figure 1: Pyramid Of Voice System Goals

Figure 1 presents a pyramid of voice system goals, the most basic of which is that of trust in the organization and the need for management to provide a "psychologically safe" environment. These are Level 1 goals in the pyramid. Once employees trust management (via psychological contracts) and the organization, they 
will be receptive to communications regarding the organization's desired image. Level 2 goals are those that deal with an organization's desired public image. A positive feeling about the organization gleaned from a psychological contract that is upheld (coupled with knowledge of the desired organizational image) sets the stage for the organization to choose among voice systems to communicate to any constituent, public or private. Level 3 goals are those that focus on voice mechanisms that can be used to target any organizational constituent. Level 3 goals can include the use of voice mechanisms to reinforce culture, allowing employees to help other employees, or showcasing an organization's image and culture to external constituents.

Management can contour the goals for specific objectives that will allow them to continue a competitive advantage. At this point, employees feel good about the organization, and understand the image that it wants to portray. Employees at this level can be expected to deliver positive messages in either organizationally sanctioned or non-sanctioned venues.

Figure 2 is an illustration of the various organizational types along with the objectives that need to be satisfied before reaching the top tier in projecting an organization's desired image to any constituent, whether public or private. It is imperative that goals be set with consideration to the organization's type. Organizations such as Strike-Out-Kings and Injured Reserves first have to rebuild the psychological contracts. Thus, the first goal would be to repair the psychological contract and build trust. Once this is done, they will have the commitment and willingness to deliver the organization's desired image (Miles and Mangold, 2005). For organizations that have repaired the psychological contract as well as Rookie organizations, the next step is to teach and reinforce the organization's desired image, which is a Level 2 goal as seen in Figure 2.

Figure 2: Course Of Action By Organizational Type

\begin{tabular}{|c|c|c|c|c|}
\hline Organizational Type & Goal of Voice & Tactics & Responsible Party & Success Indicators \\
\hline Rookie & 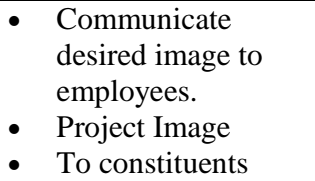 & $\begin{array}{ll}- & \text { E-mail } \\
\text { - } & \text { Intranet-build \& } \\
& \text { reinforce corporate } \\
& \text { C Blogs Wikes }\end{array}$ & $\begin{array}{l}\text { - Joint effort HR \& } \\
\text { MKT }\end{array}$ & $\begin{array}{l}\text { - Internal Blog posts } \\
\text { reflect desired } \\
\text { images }\end{array}$ \\
\hline Injured Reserve & 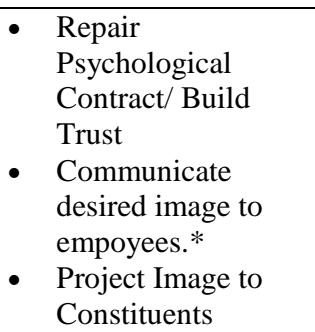 & $\begin{array}{l}\text { - Intranet } \\
\text { - Open Dialogue on } \\
\text { topics via blogs }\end{array}$ & - $\mathrm{CEO}$ & $\begin{array}{l}\text { - Good Number of } \\
\text { posts } \\
\text { - Resolutions } \\
\text { - Understanding } \\
\text { - Behavior changes }\end{array}$ \\
\hline Strike-Out Kink & $\begin{array}{ll}\text { - } & \text { Repair } \\
\text { Psychological } \\
\text { Contract/Build trust } \\
\text { - } \\
\text { Communicate } \\
\text { desired image to } \\
\text { employees. } \\
\text { - } \begin{array}{l}\text { Project Image to } \\
\text { Constituents }\end{array}\end{array}$ & $\begin{array}{ll}\text { - } & \text { Primary Intranet } \\
\text { Blog } \\
\text { - Secondary E-mail }\end{array}$ & - $\mathrm{CEO}$ & $\begin{array}{l}\text { - Interactive } \\
\text { Communication } \\
\text { - Behavioral Changes }\end{array}$ \\
\hline All Star & $\begin{array}{l}\text { Project Employee } \\
\text { brand to all } \\
\text { organizational } \\
\text { constituents }\end{array}$ & $\begin{array}{l}\text { Internet Corporate } \\
\text { web blogs }\end{array}$ & - Public relations & $\begin{array}{l}\text { - Dialogue among } \\
\text { organizational } \\
\text { constituents }\end{array}$ \\
\hline
\end{tabular}

* May not be necessary since employees know the image. But may want to be sure nothing has changed before launching into level 3 goal.

Miles and Mangold (2005) and Mangold and Miles (2007) detail the incorporation of the desired image into the message systems of the organization. Voice mechanisms can also be targeted for managers to gauge the extent to which the desired image is being displayed through the various mechanisms. As voice system 
communications reflect the desired image of the organization, organizations can move into some of the loftier goals of allowing employees to voice about the organization to external constituents on organizationally sanctioned sites.

For All-Star organizations, Level 3 goals can be targeted right from the start. Here, employees have both psychological safety and perceive their psychological contracts as intact. In addition, the organization has been successful at communicating the desired image, and that image is clearly reflected in the words and actions of its employees. One such company that has achieved All Star status is Southwest Airlines (Mangold and Miles, 2007). They have recognized new media as a means of employee voice, and are using it in a public and private domain. The private domain is for internal affairs, and the public domain is directed at being transparent to their customers (http://www.blogsouthwest.com/).

Interestingly, Southwest Airlines (SWA) has many different blogs available according to interest. A cross section of employees post entries on the corporate sanctioned blog about happenings, events, and what it is like to work at SWA. Everything is done in the Southwest Spirit. SWA has clearly captured a new dimension of employee voice through the mechanisms provided by new media. Southwest is building and maintaining emotional connections with their constituents via the new voice mechanisms. While they do not have control over employee postings to non-sanctioned blogs, they have tried to ensure that the messages posted by employees to social networking sites or other unofficial mediums are positive and reflect the organization's image.

\section{Selecting Tactics To Achieve The Objectives}

Once the purpose or objective of the voice mechanism is defined, a careful plan to accomplish this objective begins. Consideration in setting this plan has to take into account the initiator and facilitator of the voice system, the characteristics of employees for whom the system is being targeted, the message, and desired feedback and interaction. Consideration of these elements in addition to the various goals identified above will determine the most effective voice system to use. As such these elements should be discussed in accordance with the desired goals as stated above. One such goal, elaborated upon next, is the need to build trust and repair the psychological contract.

Goal: Building Trust and Repairing the Psychological contract. Before any other employee voice goals can be achieved, building trust and repairing the psychological contract has to be addressed. In some organizations such as Strike-Out-Kings and Injured Reserve the psychological contract has been damaged. These breaches cause trust issues in employees and affect their perception of whether management cares enough to respond to concerns, or if it is even safe to voice these concerns. As noted earlier both dimensions are determinants in use of the system (Milliken, Morrison, \& Hewlin, 2003; Harlos, 2001). With this in mind, lessons can be gleaned from the effective turnaround of Continental Airlines by Gordon Bethune as documented by Brennemen (1998). A very important element they identified was to restore employee confidence in management. They established a hot line, with a guaranteed response within 48 hours. Employees could expect one of three responses within 48 hours: yes we will do it; no we will not, and here is why; or we need to study this issue a little more. The two critical elements are providing a voice mechanism and a structure to ensure that employees are listened to. As with any program, accountability to the $\mathrm{CEO}$ or by the $\mathrm{CEO}$ will ensure effectiveness.

The choice of mechanism to be used in tapping the employee voice is also contingent on the audience or employees. Do employees have computer access and expertise? While younger workers are more comfortable with social networking and internet opportunities, older workers may not be. For organizations in which computer access and expertise is not prevalent, more traditional mechanisms of voice would be appropriate. For organizations in which employees have computer access and expertise, new media is a viable option. For the basic goals of building trust and the desired brand image, mechanisms allowing for internal dialogue are suggested to quarantine sensitive issues within the organization.

Given the goal of rebuilding trust and confidence, establishing an internal blog or blogs to uncover employee thoughts and concerns is fruitful. It provides for real time opportunities for employees to identify exceptions or improvements in the system, while management can address the concerns for all employees to see. This may be particularly difficult if the damage runs deep such as in Strike-Out-King organizations. It may take a few iterations of someone posting a concern, and leadership addressing the concern without repercussion before the 
new voice mechanism is taken seriously by all employees. In organizations where building trust is imperative, the CEO will need to have an active role and must ensure accountability to the commitment of the voice mechanism.

For organizations pursuing the objective of building awareness and knowledge of the organization's desired brand image, new media voice mechanisms allow for sharing and, again, real time communications. Voice mechanisms that can be used include email, blogs, and wikis. While email is one way communication and can be affective for delivering some messages, it is typically a very closed circuit in terms of feedback. Blogs and wikis certainly allow for an opportunity for organizations to construct mechanisms to profile various segments of organizational life. Wikis have also become popular in that they are similar to blogs, but contain a searchable component. Accountability of facilitating and responsibility for maintaining communications can be a little more segmented into specialty areas. For large organizations, certainly organizational issues coupled with divisional and corporate issues would provide an open forum in which exchanges can take place.

Once trust is regained, and the desired organizational image is completely understood, Level 3 goals can now be realized. The opportunities housed under Level 3 goals are numerous, and can be a system of employees helping other employees such as at Best Buy, or employees building relationships with other organizational constituents such as at SWA. Defining the purpose of the employee voice mechanism will determine whether the communications should continue in a private domain (Best Buy), or be viewable by the public such as at SWA. Again, the purpose will also dictate the sort of mechanism to use such as blogs, wikis, or even social networking sites that allow employees to chat with one another.

\section{Listening To Employee Voice}

Listening to the chatter of new media communications is pivotal in gleaning success from their use (Li \& Bernoff, 2008). From the chatter observed on the new media, one will gain insight into the internal climate of an organization. The contents of the chatter can also serve as feedback on how well the organization is fulfilling the established objectives. Depending on the feedback, new venues and avenues can open to move closer to achieving the goal or move onto fulfill higher order goals. Another component of listening is to study and research the issues to set the stage for the next level of interaction. Further investigation will lead to determining whether or not the issue has value, if it is a good opportunity for the organization, or why it won't work. Taking time to listen to the issue and investigate the issue will allow for a complete response similar to Continental's: yes we can do that: no we can't do that, and here is why; or this needs further study. How well the issues are addressed will determine whether employees will continue to expend energy to voice their opinions.

\section{Responding And Dialoguing With Employees}

After careful listening and investigation into the issues or communications of employees, great care is necessary in formulating a response. All communications should reflect the organization's values, and should follow the expected rules for new media communication and certainly reflect basic organizational values of honesty, and respect. Often times the basic rules for blogging are available for all users to read and abide by.

It is important to note that initially, the new media voice mechanism may be slow in getting off the ground. It doesn't mean employees aren't interested, they are simply watching to see how serious management takes these blogs. Often times management will need to bring up topics (even sensitive ones), before employees can exercise their voice. Rest assured they are monitoring the site and watching who is talking, responding, and assessing the quality of the responses. Past research is clear that when employees feel "psychotically sage" and management actually listens to their concerns, voice mechanisms are well used (Milliken, Morrison, \& Hewlin, 2003; Ryan \& Oestrich, 1998). The point cannot be overemphasized that effective voice mechanisms can be expected to build employee commitment, as Blinder (1990) also makes clear.

\section{Using The Voice System To Energize And Connect Employees}

Employee voice mechanisms can create a sustainable competitive advantage for organizations through positive and constructive communication among employees, managers, and other organizational constituents. As Royer et al. (2008) argue, employees are hybrid stakeholders, and articulating employee voice is a key element in 
gaining a competitive advantage. When the voice of employees is heard, the organization is trusted. Additionally, when employees also know and understand the desired image of the organization, employee satisfaction and commitment is likely to be high and turnover is likely to be low. Employees will embrace the new forum for information and be willing to share. For instance, if organizations choose Wikis to achieve an "Employee helping Employee" goal, this platform allows for filing of projects, updates, issues and policies, among other things. All the data in the system can be quickly searched to come up with the desired results. For example, the company Razorfish is organized by projects. Wikis are used to catalogue the projects, complete with project summaries, team member roles, meeting notes, documents on which those team members collaborate and schedules (Li \& Bernoff, 2008). Staff members also have pages with projects they are working on and blog about ideas they have. So anyone in the company who may have similar interests can engage others via blogs. Clark, the CEO of Razorfish, spends 15 minutes each morning listening to the chatter on the blogs, and viewing the staff pages. For managers, this is a great way to listen to what employees are thinking and doing without having to search the internet for individual postings. For employees it is a great way to see what the company and other employees are doing.

\section{CONCLUSIONS AND IMPLICATIONS FOR MANAGERS}

Employee voice - an emerging strand of contemporary organizational communication-is quickly becoming one of the most important workplace phenomena of our time thanks, in large part, to increases and improvements in the depth and breadth of technology. Technological breakthroughs have inspired new ways for employees to voice their satisfaction and dissatisfaction in the employment place in ways that were not possible only a decade ago. Social media such as Facebook, Myspace and LinkedIn as well other chat-rooms and blogs can now reach vast national and international audiences with messages that may or may not be organizationally desirable or sanctioned. The article traces the emergence of employee voice mechanisms and types, especially as the latter relates to these technology-inspired social media. The article's central contribution is to be found on many levels including, but not limited to: helping the reader to understand how an employee's choice for a voice mechanism is no longer the exclusive preserve of the organization they work for; reviewing the contextual organizational parameters that determine how and what a propensity of employees are likely to choose as their voice mechanisms; and recommending a strategy for developing and managing employee voice to enhance and sustain an organization's competitive advantage.

In reading this article up to this juncture, one point is self-evident: that a huge breadth and depth of knowledge about the opportunities and consequences of employee input through voice remains uncovered. Attendant questions here include whether or not personality (introversion versus extroversion) predicts the value that employees place on voice; whether employee voice and use of social media differs across national, regional, or multinational companies. What is clear, though, is that social media offers employees a venue to voice in either their real persona or a cloaked identity. This is supported by the recent ruling of the NLRB on Nov. 8, 2010, when they took the position that employees should not be fired for saying negative things about their employer on Facebook. It appears organizations will be afforded very little legal protection at this point.

\section{ABOUT THE AUTHORS}

Sandra Jeanquart Miles (D.B.A., S.P.H.R) is Professor of Management at Murray State University. Her research appears in journals such as Business Horizons, Journal of Management Education, Journal of Contemporary Business Issues, Journal of leadership and organizational Studies, Journal of Social Psychology, Cross Cultural Management, and Journal of Relationship Marketing. She can be reached at: Murray State University, College of Business, Department of Management, Marketing and Business Administration, 413C Business Building, Murray, KY 42071. Email: sandy.miles@ murraystate.edu

Gerry Nkombo Muuka (PhD) is Associate Dean and Professor of Management at Murray State University. His research appears in such journals as: the International Business Review, The World Bank, the Journal of Marketing Education, the Journal of Education for Business, the Journal of African Business, the International Journal of Non-Profit and Voluntary Sector Marketing, the International Journal of Social Economics, and the Scandinavian Journal of Development Alternatives and Area Studies. He can be reached at: Murray State University, Dean's Office, College of Business, 109 Business Building, Murray, KY 42071. Email: gerry.muuka@murraystate.edu 


\section{REFERENCES}

1. $\quad$ Baker, S. and Green, H. (2008) Beyond Blogs, Business Week. June 2, pp 45-50.

2. Blinder, A. (1990) Paying for Productivity, New York: Brookings Institute.

3. Brennemen, G. (1998) Right Away and All at Once: How we saved Continental, Harvard Business Review, Vo. 76, no. 5, pp. 162-179.

4. Detert, J. and Burris, E. (2007) Leadership Behavior and employee voice: is the door really open? Academy of Management Journal, Vol. 50, No. 4, pp. 869-84.

5. Dundon, T, Wilkinson, A, Marchington, M. and Ackers, P. (2004) The meanings purpose of employee voice, International Journal of Human Resource Management, Vol. 15, No. 6, pp. 1149-1170.

6. Edmondson, V. C. (2006). Organiational Surveys: A system for Employee Voice. Journal of Applied Communication Research, 307-310.

7. Farrell, D. 1983. Exit, Voice, Loyalty, and Neglect as responses to job dissatisfaction: A Multidimensional Scaling study, Academy of Management Journal, vol. 26, no. 4, pp. 596-607.

8. $\quad$ Freeman, R. and Medoff, J. (1984) What Do Unions Do? New York: Basic Books.

9. Fuller, J., Barnett, B., Hester, T., Relyea, K., and Len C. (2007) An exploratory examination of voice behavior from an impression management perspective. Journal of Managerial Issues, Spring. Taken from http://www.entrepreneur.com/tradejournals/article/print/163940483.html.

10. Gray, K.-A. G. (2009, November 2). Responding to Criticism on the Web. Retrieved November 9, 2009, from www.humanresourcesexecultive.com: http://www.hreonline.com/HRE/story.jsp?storyID=282114288\&topic=Main

11. Harlos, K.P. (2001) When organizational voice systems fail, The Journal of Applied Behavioral Science. Vol 37, no. 3, pp. 324-342.

12. HRM Guide, (2006) Managing Workplace Negativity http://www.hrmguide.net/usa/commitment/negativity.htm, retrieved June 15, 2007.

13. Hirschman, A. (1970). Exit, Voice and Loyalty. Cambridge, MA: Harvard.

14. Kassing, J. W. (2002). Speaking Up: Identifying Employees' Upward Dissent Strategies. Management Communication Quarterly, 187-209.

15. Kayany, J. (1998) Contexts of uninhibited online behavior: Flaming in social newsgroups on Usenet. Journal of the American Society for Information Science, Vol. 49, pp. 1135-1141.

16. Landau, J. (Winter 2009). When Employee voice is Met by Deaf ears. SAM Advanced management Journal, 4-12.

17. Li, C., and Bernoff, J. (2008). Groundswell. Harvard Business Press: Boston, MA.

18. McCabe D. and Lewin, D. (1992) Employee voice: A human resource management perspective. California Management Review, Vol. 34, pp. 112-123.

19. Mangold, W.G. and Miles, S.J. (2007) The employee brand: Is yours an all-star? Business Horizons, Vol. 50, pp. 423-433.

20. Miles, S.J. and Mangold, W.G. (2005) Positioning Southwest Airlines Through Employee Branding, Business Horizons, Vol. 48 No. 6, pp. 535-545.

21. Miller, C. (2008) In a twitter age, even layoffs are on the company blog, International Herald Tribune, http:www.iht.com/bin/printfriendly.php?id=17534995, retrieved 11-05-2008.

22. Milliken, F., Morrison, E. and Hewlin, P. (2003) An Exploratory Study of Employee Silence: Issues that employees don't communicate upward and why, Journal of Management Studies, Vol, 40, pp. 1453-1476.

23. Millward, N., Bryson, A. and Forth, J. (2000) All Change at Work: British employment relations 19801998 as portrayed by the Workplace Industrial Relations Survey Series. London: Routlege.

24. Niehoff, B.P. and Paul, R.J. (2001) The Just Workplace: Developing And Maintaining Effective Psychological Contracts, Review of Business, Vol. 22, No. 1/2, (Spring/Summer), pp. 5-8.

25. Niemz, K., Griffiths, M, and Banyard, P. (2005) Prevalence of pathological internet use among university students and correlations with self-esteem, the General Health Questionnaire (GHQ), and disinhibition, CyberPsychology \& Behavior, Vol. 8, pp. 562-570

26. Pontin, J. (2007) From many tweets, one loud voice on the internet, New York Times Online, http://www.nytimes.com/2007/04/22/business/yourmoney/22stream.html?_r=1\&scp=1\&sq=Twitter\%20Po ntin\&st=cse, retrieved Nov. 15, 2008. 
27. Richmond, M, (2006) Pew Internet: Who Blogs, Really? and Why? http://www.blogher.com/node/7891. Retrieved: 9-26-2008

28. Robinson, S.L. (1996) Trust and Breach Of The Psychological Contract, Administrative Science Quarterly, Vol. 41 No. 4, pp. 574-600.

29. Rousseau, D. (1989) Psychological And Implied Contracts In Organizations, Employee Responsibilities and Rights Journal, Vol. 2, pp. 121-139

30. Rousseau, D. (1995) Psychological contracts in organizations: Understanding written and unwritten agreements, Sage Publications, Thousand Oaks, CA.

31. Royer, S. Waterhouse, J., Brown, M.F., (2008) Employee voice and strategic competitive advantage in international modern public corporations-an economic perspective. European Management Journal, Vol. 26, pp. 234-246.

32. Ryan, K and Oestreich, D. (1998) Driving fear out of the Workplace (2 ${ }^{\text {nd }}$ edition), San Francisco: JosseyBass.

33. Southwest Airlines. (2011). Spreading Low Fares Farther. http://www.lowfaresfarther.com/ Retrieved: $1 / 25 / 2011$.

34. VanDyne, L., Ang, S. and Botero, C. (2003) Conceptualizing employee silence and employee voice as multi-dimensional constructs, Journal of Management Studies, Vol. 40, pp. 1359-1392.

35. VanDyne, L., and LePine, J.A., (1998) Helping and voice extra-role behaviors: Evidence of Construct and Predictive Validity, Academy of Management Journal, Vol. 41 pp. 108-119.

36. William C. Martucci, K. A. (2010, January 1). Retrieved January 1, 2010, from http://www.law.com/jsp/lawtechnologynews/PubArticleFriendlyLTN.jsp?id=1202439369681 


\section{$\underline{\text { NOTES }}$}

